\title{
Determinants of Bank Credit Growth in Ethiopian Private Commercial Banks
}

\author{
Habtamu Alebachew ${ }^{1 *} \quad$ Zemenu Fekede ${ }^{2}$ \\ 1.Lecturer, Department of Accounting and Finance, DireDawa University, DireDawa, Ethiopia \\ 2.Lecturer, Department of Accounting and Finance, Mettu University, Mettu, Ethiopia
}

\begin{abstract}
This study is mainly aimed to investigate factor that determine the growth of credit of private commercial bank of Ethiopia by using data for 9 years by Eviews through the use of OLS. Both descriptive and econometric analysis has been applied in order to investigate factors that determine growth of loan in the case of private commercial banks in Ethiopia. As determinants GDP, Inflation, Bank liquidity, population growth rate, unemployment rate and deposit growth were included. The result of the econometric result indicates GDP, inflation, bank liquidity and deposit growth are found to have significant positive impact for the growth of private banks credit. However, population growth rate has a positive but insignificant effects on credit growth, contrarily unemployment rate has a negative and insignificant effect on credit growth of private commercial banks. The study recommends policymakers should control variations in Economic growth and inflation to maintain the stability of credit flows to the different sector. Clearly, these variables are closely linked to monetary policy actions, and the results generally show that macroeconomic stability is vital for the flow of credit in Ethiopia.
\end{abstract}

Keywords: Credit growth, private banks and macro-economic factor

DOI: $10.7176 / \mathrm{DCS} / 11-2-03$

Publication date: February $28^{\text {th }} 2021$

\section{Introduction}

As per the Pan African bank report Dec 30, 2014, the Ethiopian banking industry constitutes the most important element of the Ethiopian financial service sector because it accounts for nearly 80 percent assets of financial service industry. As banks act as the main players in channelling funds from lenders to borrowers, it is important that their intermediary role is carried out with the lowest possible costs in order to encourage investment and to achieve higher social welfare. After financial sector reform NBE impose control over deposit rates in order to keep the lending rates low i.e. set the minimum saving deposit interest rate and leaving lending rate to commercial banks with the aim of improving efficiency in the intermediation process by reducing the interest rate margin. However, this seems not to have been realized in Ethiopia since 2002 (Kozo et al., 2007).

The economic development of any country depends on the existence of well-organized financial system. Financial institutions are one important components of financial system of a given country. (www.envestopedia.com). As Ethiopian financial system is bank dominated, banks are a part of those institutions which accept deposit from economic agents and then lend this funds to make direct loans or invest in security like stocks and bonds (Cambel Harvey, 2010). Banks operates by charging interest as well as operates without charging interests. Interest is fee paid for usage of others money. To the borrowers it is the cost of renting money to the lender it is income for lending the money. Banking as a business involves receiving funds from the public by accepting demand, time and saving deposits or borrowing from the public or other banks, and using such funds in whole or in part for granting loans, advances and credit facilities and for investing funds by other means. Thus, banks facilitate the savings and capital formation in the economy (Chirwa, 2001).

According to Simegnew (2020), in Ethiopia, there is an increasingly growing public and private investment in the area of infrastructure, agriculture, manufacturing, and processing etc. which seeks for continues supply of finances. Intermediation functions of banks play a vital role in the efficient allocation of resources of countries like Ethiopia by mobilizing resources for productive activities. Even though, the total deposit mobilized by commercial banks in Ethiopia is not sufficient to meet the required loan because in 2018 annual report of NBE the total deposit of Ethiopian commercial banks was 730 billion while the total loan require was 733 billion. This shows that the level of credit that banks grants to customer is in its infant stage.

Furthermore, Ethiopian private commercial banks play an important role for the development and success of various private business organizations in the country by providing finance (Habtamu, 2017). Even if their role is vital, they don't have sufficient deposit in their treasury to meet the demand for loan customers (NBE, 2018). Therefore, the researchers want to examine those factors determining the growth of bank credit of sample private commercial banks in Ethiopia from the year (2010-2019).

\section{Statement of the Problem}

Financial institutions play great role within a given countries economy by intermediating resource from lenders 
to borrowers. The low level of investment in developing countries largely attributed to the low level of saving, low level of job opportunity and low level of economic growth (Rodney Wilson 1986). It is unquestionable that investment plays a leading role for the growth of a countries economy but this requires the accumulation of capital and appropriate allocation of accumulated capital.

There were many bank failures before, during and after the financial crisis of 2007-2009 in all over the world due to unable to satisfy customers need and then lead to bankruptcy (FDIC, 2019). In USA and other developed countries several commercial banks were failed due to their weakness to satisfy the need of customer, these includes Southern Pacific Bank, Dollar Savings Bank, Metropolitan Savings Bank, First Integrity Bank, NA, The First State Bank, City National Bank of New Jersey, Highland Community Bank and so on (FDIC, 2019). Recently, the issue of credit has become one of the hot and debated issue in the field of finance due to the failure of some commercial banks in the world and its adverse effect on the performance of banks.

Commercial banks and Development Bank of Ethiopia (DBE) disbursed Birr 164.5 billion in fresh loans which was 42.5 percent higher than that of a year ago. Of the total new loans, about 60.8 percent was provided by private banks and 39.2 percent by the two state owned banks. Nearly, 25.3 percent of the loans went to finance industry sector followed by domestic trade (20 percent), international trade (16.8 percent), other sectors (10.5 percent), housing and construction (11.9 percent), and agriculture (10.9 percent). The remaining balance went to other economic sectors (NBE, 2018/19).

The empirical studies suggest that; determinants of bank credit growth are numerous and vary across countries and regions. In the context of Ethiopia, no, one give attention to examine the factors affecting the growth of bank credit, rather most of them assess the factors affecting credit risk of commercial banks.

\section{Objectives of the study}

To establish the effect of bank specific and macro-economic variables on private commercial bank credit growth.

\section{Empirical literature review}

A study of Akinlo and Oni (2015), The paper analyses the dominant factors influencing bank credit to private sector in Nigeria over the period 1980-2010 using the error correction modeling technique. The results show that broad money, cyclical risk premium and liquidity ratio tend to increase credit to the private sector. However, prime lending rate and reserve ratio lead to a reduction in credit to the private sector. Private credit increases with inflation, but not one to one, meaning that inflation tends to dampen real bank credit to the private sector.

According to Gideon et al. (2017) Using the Autoregressive Distributed Lag (ARDL) framework, this paper examines the relevant factors influencing allocation of bank credit to the private sector in the Ghanaian economy for the period 1970 to 2011 . The results show that broad money supply, bank assets, real lending rate, and bank deposits are significant determinants of bank credit in both the short and long-run. Inflation also exerts significant positive impact only in the short-run. The study infers the lack of successive governments' commitment to pursue policies that boost the supply of credit to the private sector.

Tuyen and Diep (2018) Assess Determinants of Banks' Lending Growth in Vietnam considering both demand and supply side factors but putting more emphasis on bank diversification strategies. It is found that banks' geographical and income diversification strategies are beneficial in terms of their ability to maintain growth rate in credit supply. As for demand factors, economic growth has a positive impact on loan growth, while inflation poses a negative influence on loan growth. Surprisingly the impact of 2008-2009 global financial crisis does not show any significant impact on the lending growth. As expected, an increase in banks' deposit leads to higher credit growth. The study further confirms that strong banks' balance sheets, in terms of low nonperforming loans and low solvency ratio has a positive effect on credit supply.

Yasnur and Kurniasih (2017), examine and analyse the effect of Interest Rate, Economic Growth, Funding Growth, Capital Adequacy Ratio (CAR) and Non-Performing Loan (NPL) of Lending Growth Banks. Research data is annual data for 5 (five) years observation (December 2011 until December 2015). The sampling method used was purposive sampling. From a population of 40 Private Commercial Banks and Foreign National listed in Indonesia Stock Exchange (IDX), 30 Banks met the criteria to be the sample. The result showed that Economic Growth, Funding Growth and NPL are having positive and significant influence to Lending Growth Banks. BI Rate and CAR are having positive influence but not significant to Lending Growth Banks. Economic Growth is the most significant variable in influencing Lending Growth Banks.

According to Shingjergji and Hysen (2015), in analyze of the influence of some macroeconomic and banking factors on credit growth in the Albanian banking system. They use credit growth as a dependent variable while as independent variables we use: GDP growth, inflation rate, unemployment rate, loan interest rate, capital adequacy ratio, bank size and NPL ratio. The relationship between credit growth and macroeconomic and banking factors was tested by using a regression model like the ordinary least squares (OLS). We take into consideration a period from 2002 - 2013 using quarterly panel data for the whole Albanian banking system with a total of 48 observations per each variable. The regression results find out that the credit growth in the Albanian 
banking system is positively related to GDP growth, inflation rate and capital adequacy ratio while is negatively related to unemployment rate, interest rate, non-performing loans and bank size.

Al-Shammaria and El-Sakkab (2018), investigates the determinants of credit growth in the private sector across some of the Organization for Economic Cooperation and Development (OECD) countries. The data set covers 24 countries and uses quarterly data over a period from the fourth quarter of 2001 to the fourth quarter of 2013. Panel unit root tests, indicate that the series used are stationary at their first difference form, and cointegration tests indicate that a long-term relationship exists among the series in the panel. Generalized impulse response functions and forecast variance decomposition are analysed. The results indicate that, in the long-run, the main determinants of bank credit growth for OECD countries are exchange rates, foreign liabilities, money supply, interest rates, inflation, GDP, and fixed capital formation (FCF). The study shows that macroeconomic stability seems to be vital for the flow of credit to the private sector across OECD countries.

Guo and Stepanyan (2011), examine changes in bank credit across a wide range of emerging market economies during the last decade. The rich time-series and cross-section information allows us to draw broader lessons compared to many existing researches, which focus on a specific set of emerging market economies or on shorter time periods. Our results show that domestic and foreign funding contribute positively and symmetrically to credit growth. The results also indicate that stronger economic growth leads to higher credit growth, and high inflation, while increasing nominal credit, is detrimental to real credit growth. We also find that loose monetary conditions, either domestic or global, result in more credit, and that the health of the banking sector also matters.

According to Awdeh (2017), in the study aims at defining the credit growth determinants in Lebanon by exploiting a panel data of 34 commercial banks over the period 2000-2015. The empirical results show that deposit growth, GDP growth, inflation, and money supply, all boost bank credit to the resident private sector. Conversely, credit risk, lending interest rate, T-bill rate, public borrowing, and remittance inflows decrease loan growth. We extend our analysis and detect the impact of one-year lag of all exploited variables in order to find out if they have a delayed impact on credit growth, where we find several different results. For instance, lag LLP recorded the opposite effect of LLP; ROA does not affect credit growth, whereas its lag lowers credit growth; the impact of a change in money supply amplifies considerably after one year; and finally, the negative impact of remittances fades away after one year.

\section{Literature gap}

Those the above studies were conducted outside Ethiopia. In context of Ethiopia no study can be done in this area. In addition to this the above empirical studies reveal different findings for the same variables. So, they lack consistency.

\section{Hypothesis to be tested}

GDP, inflation, population growth rate, bank liquidity, unemployment rate, and deposit growth have significant impact on the growth of credit of commercial banks.

\section{Source of data}

In this study secondary data was used as a source of information.

\section{Method of data collection}

As the sources are identified secondary sources of data was used to get realistic information from concerned bodies. In order to collect secondary data bank document, management information system department and other published works are utilized.

\section{Research Design}

This cross-sectional study was conducted based on causal research design by using multiple linear regression model.

\section{Data collection and Methods of Data Analysis}

To achieve the objective of the study, the study was primarily based on panel data that were collected through structured document review. In order to test proposed hypotheses, a statistical analysis was carried out using the following methods: First, descriptive statistics of dependent and independent variables was calculated over the sample period. This is in line with Malhotra (2007), which states that using of descriptive statistic methods help the researchers in picturing the existing situation and allows gathering of relevant information. Then, correlation analysis among dependent and independent variables was made. 


\section{Econometric Model}

In order to empirically examine determinants of bank credit growth, researcher used linear multivariate regression which has been extensively applied in the previous finance literature.

$\mathrm{CRit}=\beta 0+\beta 1$ (GDPit) $+\beta 2$ (UNEit) $+\beta 3$ (INFit) $+\beta 4$ (LIQit) $+\beta 5$ (POPit) $+\beta 6$ (BDGRit) + cit........................................... (equation 1$)$

Where,

$\mathrm{CR}=$ credit growth

$\beta 0=$ constant

$\beta=$ coefficient

GDP $=$ Gross domestic product

$\mathrm{UNE}=$ unemployment rate

$\mathrm{INF}=$ inflation

LIQ = bank liquidity

POP $=$ Population growth

BDGR $=$ Bank deposit growth rate

\section{Chapter 4}

\section{Analysis and interpretation}

\begin{tabular}{|c|c|c|c|c|c|}
\hline \multicolumn{6}{|c|}{ Descriptive Statistics } \\
\hline & $\mathrm{N}$ & Minimum & Maximum & Mean & Std. Deviation \\
\hline $\mathrm{CRG}$ & 63 & .1088 & .8019 & .306848 & .1875561 \\
\hline GDP & 63 & .077 & .114 & .09500 & .011620 \\
\hline INF & 63 & .07400000001 & .34100000000 & .1397777778 & .07951081443 \\
\hline UNE & 63 & .02080000 & .02300000 & .0218888889 & .0007829092 \\
\hline BDGR & 63 & .0334 & .8076 & .265116 & .1484613 \\
\hline LIQ & 63 & .4050 & .8912 & .625322 & .0852314 \\
\hline POP & 63 & .026100000 & .028700000 & .0277000000 & .0009323916 \\
\hline
\end{tabular}

On average credit growth of commercial banks measured by the annual change in level of credit from 10.88 to 80.19 percent. It has a mean of $30.68 \%$ and standard deviation of $18.75 \%$ which reveal an increasing of credit with in the study period.

Gross domestic product has range from minimum of $7.7 \%$ to maximum of $11.4 \%$. It has a mean of $9.5 \%$ with standard deviation of $11.62 \%$. and inflation has range from minimum of $7.4 \%$ to maximum of $34.1 \%$. It has a mean of $13.9 \%$ with standard deviation of $7.9 \%$.

Unemployment has range from minimum of $20.8 \%$ to maximum of $23 \%$. It has a mean of $21.8 \%$ with standard deviation of $0.07 \%$. and bank deposit growth has range from minimum of $3.34 \%$ to maximum of $80.7 \%$. It has a mean of $26.5 \%$ with standard deviation of $14.8 \%$.

Bank liquidity has range from minimum of $40.5 \%$ to maximum of $89.12 \%$. It has a mean of $62.5 \%$ with standard deviation of $8.5 \%$. and population growth rate has range from minimum of $26.1 \%$ to maximum of $28.7 \%$. It has a mean of $27.7 \%$ with standard deviation of $0.09 \%$.

The mean values of all the research variables lie within their maximum and minimum values showing a good level of consistency. 
Final fitted multiple linear regression model

Dependent Variable: CRG

Method: Panel Least Squares

Date: 02/03/21 Time: 02:12

Sample: 20112019

Periods included: 9

Cross-sections included: 7

Total panel (balanced) observations: 63

Variable

Coefficient

Std. Error

t-Statistic

Prob.

\begin{tabular}{crrrr}
\hline \hline & & & & \\
GDP & 6.549077 & 2.584678 & 2.533808 & $* 0.0145$ \\
INF & 1.163044 & 0.374910 & 3.102195 & $* 0.0032$ \\
POP & 138.1649 & 79.42373 & 1.739593 & $* * 0.0881$ \\
UNE & -238.8441 & 124.5019 & -1.918397 & $* * 0.0608$ \\
LIQ & 1.140786 & 0.291612 & 3.911995 & $* 0.0003$ \\
BDGR & 0.541342 & 0.162268 & 3.336090 & $* 0.0016$ \\
C & 0.066104 & 1.063571 & 0.062153 & 0.9507
\end{tabular}

“*” shows statistical significance@10\% and “**” shows significance @ $5 \%$

From the six explanatory variables GDP (p- value 0.0145$)$, inflation ( $p$ - value $=0.0032$ ), bank liquidity (pvalue $=0.0003)$ and bank deposit growth $(p$-value $=0.0016)$ have statistically significant effect on the growth of credit of private commercial banks. But population growth and unemployment rate have a significant impact on the growth of banks credit at $10 \%$. As we observed above only unemployment has a negative impact on credit growth of private commercial banks. All remaining variables have a positive effect on the dependent variable.

Credit growth $=0.066104+6.549077 *$ GDP $+1.163044 *$ Inflation $+138.1649 *$ population growth rate + $1.140786 *$ liquidity $+0.541342 *$ deposit growth $-238.8441 *$ unemployment

Making the effect of all independent variables zero, on average, total credit will decrease

As it can be seen from the regression model, for a unit increase in the amount of GDP, the total credit increases by 6.549077 which is significant and has positive effect. As it can be seen from the regression model, for a unit increase in the amount of inflation, the total credit increases by 1.163044 which is significant and has positive effect. for a unit increase in the amount of population growth rate, the total credit increases by 138.1649 which is insignificant and has positive effect. for a unit increase in the amount of unemployment rate, the total credit increases by -238.8441 which is insignificant and has negative effect. As it can be seen from the regression model for a unit increase in the amount of bank liquidity, the total credit increases by 1.140786 which is significant and has positive effect. As it can be seen from the regression model. for a unit increase in the amount of bank liquidity, the total credit increases by 1.541342 which is significant and has positive effect. 
Model Assumption check

Homoscedasticity (Constant variance assumption)

The test of heteroscedasticity is a test of the second assumption of OLS estimator that says the variance of errors is constant. The researcher used Breusch-Pagan / Cook-Weisberg test of heteroscedasticity.

Ho: The assumption that there exists Homoscedasticity

H1: There is no Homoscedasticity (there is heteroscedasticity)

Heteroscedasticity

Heteroscedasticity Test: Breusch-Pagan-Godfrey

F-statistic

Obs*R-squared

Scaled explained SS

$$
\begin{array}{ll}
0.226929 & \text { Prob. F(6,56) } \\
1.495411 & \text { Prob. Chi-Square(6) } \\
2.032334 & \text { Prob. Chi-Square(6) }
\end{array}
$$

test for heteroscedasticity Eviews output displays tests for heteroscedasticity and we don't have enough evidence to reject the null hypothesis of Homoscedasticity presence. Therefore, it can be concluded that the variance of error term is constant or the second assumption of classical linear regression model is not violated.

Test of multicollinearity

\begin{tabular}{cc}
\hline \hline & Centred \\
Variable & VIF \\
\hline \hline BDGR & 1.279671 \\
GDP & 3.217546 \\
INF & 3.227358 \\
LIQ & 1.889291 \\
POP & 9.35132 \\
UNE & 7.91477 \\
C & NA
\end{tabular}

Since, none of the variables above show variance inflation factor (VIF) greater than 10, there is no series Multicollinearity problem among the explanatory variables.

\section{Normality Test}

Hypothesis test of normality

Ho: The residuals are normally distributed

H1: The residuals are not normally distributed

The p-value (0.3432) given at the test for normality is bigger than 0.05 . Hence, we fail to reject the null hypothesis of normality and declare that the presence of normality of the data at the $5 \%$ level of significance (Brooks, 2008). Thus, the assumption of the residuals is normally distributed is not violated.

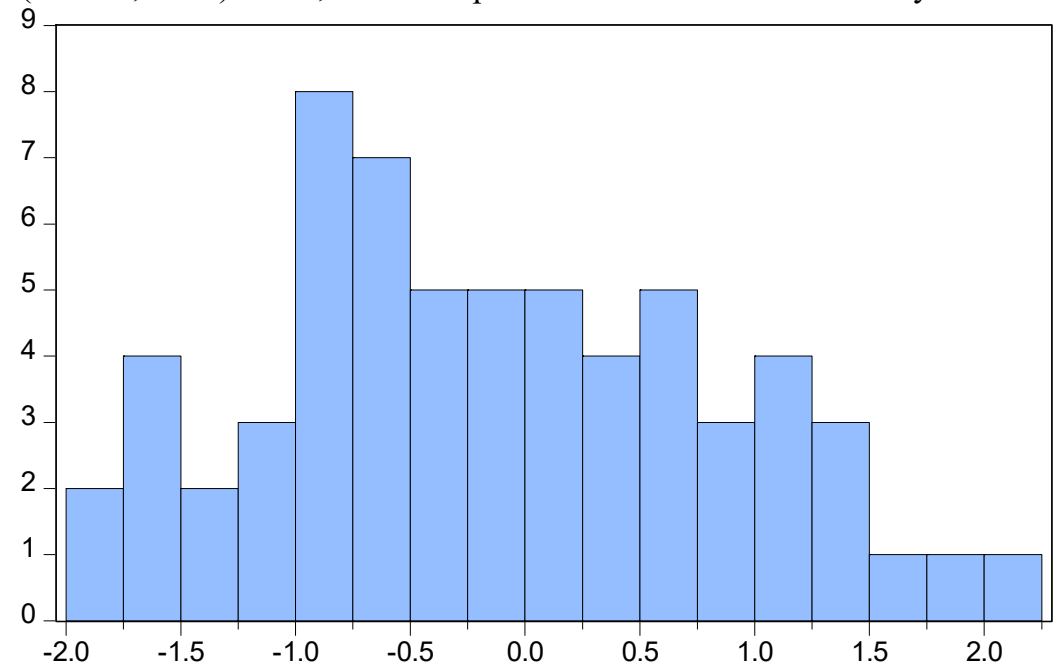

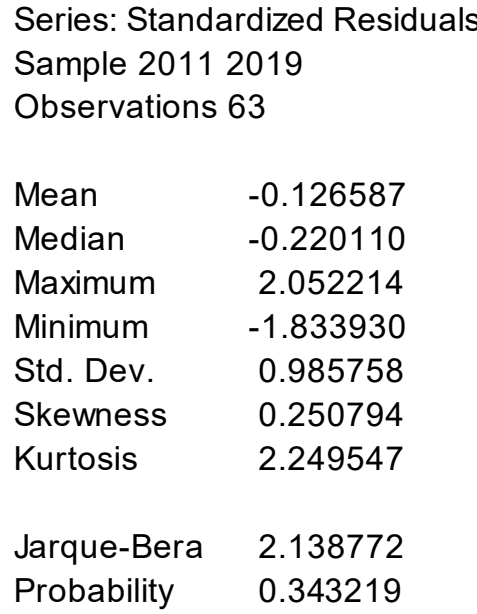

Conclusion and Recommendation

\section{Conclusion}

Based on the result of the finding this study has drawn the following relevant conclusion.

This study aims to examine the effects of macro-economic and bank specific factors on private banks' loan 
growth in Ethiopia. The research findings show that bank specific factors are beneficial in terms of their capability to promote loan growth. Population growth and unemployment rate are found to be not a significant determinant for loan growth, suggesting that Unemployment and population growth do not aim to increase market share in lending activities. Demand factors such as GDP growth and inflation again confirm their important role in determining the growth rate in credit supply.

\section{Recommendation}

policymakers should control variations in Economic growth and inflation to maintain the stability of credit flows to the different sector. Clearly, these variables are closely linked to monetary policy actions, and the results generally show that macroeconomic stability is vital for the flow of credit in Ethiopia.

Banks should be keen to take advantage of the Economic Growth that is happening. When the Economic Growth is improving, it can be used as a good momentum for the business development strategy by implementing relevant strategies and the corresponding ability of the company. In addition, the Economic Growth, Funding Growth the greater it will make the greater the amount of Credit Bank that can be coordinated.

\section{Reference}

1. Ali Awdeh (2017), The Determinants of Credit Growth in Lebanon, International Business Research

2. Al-Shammaria N and Mohammed El-Sakkab (2018), Macroeconomic Determinants of Credit Growth in OECD Countries INTERNATIONAL JOURNAL OF BUSINESS.

3. Akinlo, A. Enisan and Oni, I. Oluwafemi, Determinants of bank credit growth in Nigeria 1980-2010, European Journal of Sustainable Development.

4. Brooks, C. (2014). Introductory Econometrics of Finance 3rd ed. the ICMA Center, University of Reading, Cambridge University press.

5. Cambel Harvey, 2010, Hypertextual finance glossary, University of Duke

6. Chirwa, E. W. (2001). Market Structure, Liberalization and Performance in the Malawian Banking Industry. African Economic Research Paper, No. 108, Nairobi.

7. FDIC, 2019 report

8. Gideon Baokoa, Isaac Attah Acheampongb and Muazu Ibrahim, (2017) Determinants of bank credit in Ghana: A bounds-testing cointegration approach, African Review of Economics and Finance

9. Guo, K., and Stepanyan, V. (2011) "Determinants of Bank Credit in Emerging Market Economies" IMF Working Paper WP/11/51.

10. Habtamu. (2017). The role of Ethiopian private commercial banks in private Business organizations. Journal of Finance, 24-33

11. Malhotra, N. (2007.). Marketing Research: An applied Orientation, 5th Edition. New Delhi

12. National bank of Ethiopia, 2018/2019 Annual report

13. Roddney Wilson, (2010), Islamic banking and finance in European union, university of Durham and INCEIF

14. Simegnew, m. (2020). determinants of deposit growth. an emperical study on Ethiopian private commercial banks. bahirdar university, 1-57.

15. Tuyen.N and Diep N. (2018); Determinants of Banks' Lending Growth in Vietnam, Pacific Business Review International.

16. Yasnur M and Kurniasih (2017). Factors Affecting Bank Lending Growth: Cases In Indonesia, International Journal of Scientific and Research Publications. 